УДК 788.41.071.2

ORCID: 0000-0003-0823-0305

Євген Чуріков, аспірант Луганського національного університету імені Тараса Шевченка (м. Полтава), артист Національного заслуженого академічного симфонічного оркестру Украӥни (м. Киї)

Ievgen Churikov, Postgraduate at the Lugansk National University named after Taras Shevchenko (Poltava), Artist of the National Honored Academic Symphony Orchestra of Ukraine (Kyiv)

\title{
ФЕНОМЕН ВАЛТОРНОВОГО ВИКОНАВСТВА
}

3'ясовано, що валторнове виконавство є складним утворенням, в якому система технічних умінь $\mathrm{i}$ навичок забезпечує успішність художньої інтерпретації музичних творів, а також стає джерелом ефективної виконавської діяльності. Розглянуто певні ознаки, які відповідають категорії «виконавська школа». Визначено особливості та традиції основних світових шкіл валторнового виконавства (європейська, американська, російська, українська).

Ключові слова: валторна, валторнове виконавство, європейська школа валторнового виконавства, американська школа валторнового виконавства, російська школа валторнового виконавства, українська школа валторнового виконавства.

The phenomenon of horn performance. It was found that horn performance is a complex activity where the system of technical knowledge and skills ensures the success of the artistic interpretation of musical compositions and becomes the source of efficient performance activities as well. The specific features that correspond to the category of «performance school» have been considered. The special aspects and traditions of the world core schools for horn performance (European, American, Russian and Ukrainian) have been identified.

Key words: horn, horn performance, European school for horn performance, American school for horn performance, Russian school for horn performance, Ukrainian school for horn performance.

Феномен валторнового исполнительства. Выяснено, что валторновое исполнительство является сложным образованием, в котором система технических умений и навыков обеспечивает успешность художественной интерпретации музыкальных произведений, a также становится источником эффективной исполнительской 
деятельности. Рассмотрены некоторые признаки, которые соответствуют категории «исполнительская школа». Определены особенности и традиции основных мировых школ валторнового исполнительства (европейская, американская, российская, украинская).

Ключевые слова: валторна, валторновое исполнительство, европейская школа валторнового исполнительства, американская школа валторнового исполнительства, русская школа валторнового исполнительства, украинская школа валторнового исполнительства.

Актуальність теми дослідження. Сучасне музичне мистецтво пред'являє високі вимоги до рівня професійної оснащеності виконавцяінструменталіста, зокрема валторніста. Музика старих майстрів, твори епох класицизму й романтизму, твори створені видатними вітчизняними i зарубіжними композиторами XX та ХXI століття, ставлять перед валторністом складні творчі завдання, які неможливо вирішувати, не володіючи високоорганізованою виконавською майстерністю. Тому і на початку третього тисячоліття ці питання, безумовно, залишаються актуальними не тільки для теорії і практики виконавства, валторнової педагогіки, а й для музикознавства в цілому.

Методологія дослідження грунтується на застосуванні мистецтвознавчого, компаративного, педагогічного методів, основаних на принципі історизму, відповідно до якого всі явища розглядаються в процесі розвитку і взаємозв'язку з конкретними умовами.

Наукова новизна. Досліджено розвиток валторнового виконавства та відзначено його особливості та традиції, які висвітлені у чотирьох основних світових школах валторнового виконавства: європейській, американській, руській, українській.

Мета дослідження - розглянути особливості валторнового виконавства.

Феномен валторнового виконавства постає сьогодні як результат діяльності багатьох поколінь виконавців-духовиків і педагогів, як результат історії, яка безперервно змінюється, особливо на стику різних культурних епох.

За три останніх століття науково-теоретична i методична думка духовиків-виконавців і педагогів пройшла в своєму розвитку великий i плідний шлях. Незважаючи на досягнення сучасного музикознавства в галузі духового розвитку виконавство на валторні є найменш вивченою сферою.

Завдяки науково-педагогічній діяльності вітчизняних (В. Антонов, В. Апатський, В. Богданов, В. Вдовиченко, П. Вовк, П. Круль, В. Качмарчик, В. Посвалюк, Ф. Крижанівський та ін.) та закордонних (В. Блажевич, Б. Диков, В. Сумеркін Ю. Усов, Х. Кунітц, П. Луцкер, І. Сусідко та ін.) викладачів-духовиків і науковців XX-XXI ст. в музикознавстві створено 
потужний науковий потенціал. Дослідники розглянули різні аспекті теорії i практики гри на духових інструментах відповідно до їх специфіки.

У сфері музикознавства, орієнтованої на валторнову виконавську проблематику розглянуто питання з історії зародження валторни та опис iï конструктивних особливостей (В. Буяновський); аналіз валторнових концертів і останніх симфоній В. Моцарта (Г. Аберт); інтерпретації партії валторни в музиці різних стилів і епох (А. Вдов); еволюція валторни в симфонічної партитури та вплив виконавської практики на формування оркестрових стилів (Л. Бєлєнов); стилістичні особливості жанру інструментального концерту і принципи трактування валторни як сольного інструмента (П. Луцкер, І. Сусидко); розвиток виразних і технічних можливостей валторни (Ю. Гриценко, П. Луцкер, I. Семеряга, Ф. Шоллар); способи звукоутворення, проблеми і складності інтонування (X. Кунітц); методичні питання виконавства на валторні (Л. Полєха, А. Усов, Ю. Усов, А. Федотов, І. Якустіді).

Значна кількість наукових робіт дають нам матеріал для аналізу та розуміння феномену валторнового виконавства i виявлення відмінностей різних виконавських шкіл.

Для того, щоб відповідати категорії «виконавська школа», інструментальне виконавство повинно володіти певними ознаками, які об'єднані в цілісну систему, а саме:

- $\quad$ єдність основних художніх і технологічних принципів виконання;

- групою музикантів-учнів або послідовників відомого виконавця, що об'єднані спільністю творчих принципів і художньої манери виконання;

- $\quad$ високим рівнем виконавчої майстерності послідовників даної школи; серійністю високих результатів;

- $\quad$ єдинством та наслідуваністю методів навчання на інструменті;

- $\quad$ групою педагогів, що притримуються єдиної системи цілей, завдань та методів навчання [1].

Результати методичних напрацювань видатних валторністів, педагогів щодо вдосконалення виконавської техніки відбились не тільки у розробці методичних посібників, а й у створенні окремих виконавських шкіл.

Так, у практиці гри на валторні відзначається різні між собою традиції валторнового виконавства, тобто чотири основні виконавські школи, а саме: європейська, американська, російська, украӥнська.

Європейська школа валторнового виконавства найбільш старовинна i має свої традиції та особливості. Не зважаючи на те, що вона поєднала в собі риси багатьох національних виконавчих шкіл країн Західної і Східної Свропи, 
завжди зберігала свої основні особливості: сурове, академічне ставлення до звуковидобування, звуковедения, тембру, інтонації та до авторських ремарок.

Гра європейських валторністів відрізняється високою вимогливість до виконання творів, а саме: безпомилкове і абсолютно точне виконання нотного тесту, бездоганна чистота інтонування, чистий і без призвуків тембр, точне виконання ритмічних рисунків. Свропейська школа протягом століть культивувала чистий, відкритий і ясний звук, чітку артикуляцію [3].

Виконавство на валторны європейців, як правило, відрізняється саме обмеженим використанням тембрових і динамічних засобів виразності, оскільки академічність, прагнення до бездоганної точності в певній мірі обмежують поле для творчої ініціативи виконавця.

Американська школа валторнового виконавства відрізніється від інших шкіл, перш за все це стосується звуковидобування, особливість його в тому, що звук після відтворення стає голосніше і змінюється тембр. Представники європейської школи і $\dddot{1}$ послідовники, стверджують, що це порушення так званого принципу «конуса» в звуковидобуванні. Але американські валторністи, не тільки ігнорують цей принцип, але i зробили 3 його порушення особливий прийом виразності. Уявлення про звучання валторни в американській школі інше, вона звучить значно важче і втрачає свої звичні риси. В силу цих відмінностей між звучанням європейської і американської валторни, все частіше в валторновому світі говорять про те, що в руках американських виконавців звук валторни втрачає свої звичні риси. Валторна перестає бути валторною, а стає якимось новим інструментом.

Методичні напрацювання та практичні досягнення видатних педагогів-музикантів минулого щодо вдосконалення валторнового виконавства стали основою створення валторнових шкіл, у яких формувалися принципи роботи над технікою.

Російська школа валторнового виконавства - одна з великих, яка має давню історію. Мистецтво гри на валторні прийшло в Росію 3 країн Європи. Незважаючи на те, що традиції гри на валторні в Росії мають досить давню історію, російська школа валторнового виконавства сформувалася значно пізніше появи перших російських валторністів. Це пов'язано з тим, що протягом тривалого періоду в музичному житті Росії панували іноземні музиканти, яких спеціально запрошували з-за кордону. Засновником валторнової школи в Санкт-Петербурзі був російський валторніст, педагог і композитор, за національністю німець Фрідріх Християнович Гоміліус [2]. 
Першим навчальним закладом, який поклав початок формуванню російської виконавської школи гри на духових інструментах була Петербурзька Придворна співацька капела. В інструментальних класах капели викладали гру на всіх духових інструментах, в тому числі і на валторні. Співаки, що навчалися в інструментальних класах капели, вже мали певні музичні навички вокальної артикуляції і звуковедення, які сформувалися за час навчання співу. Як відомо, на російське валторнове виконавство величезний вплив справило те, що валторністами ставали колишні вокалісти, які співали.

Класом валторни в Петербурзькій співацькій капелі керував чеський валторніст і арфіст, педагог, диригент, композитор, випускник Празької консерваторії Франц Шоллар. Він все життя працював поряд зі співаками, що вплинуло на його педагогічні погляди. Саме специфіка роботи в капелі навела його на думку використовувати в якості навчального матеріалу російські та українські народні пісні [5], які мають можливість більш точного звуковидобування, краси та виразності. Так, Ф. Шоллар поєднав, в свойй методиці грі на валторні, європейську академічність 3 народнопісенною мелодичністю.

У Москві традиції гри на валторні збагачувалися новими оригінальними якостями, які присутні В. Буяновському, С. Вишневському, А. Глухову, П. Делію, С. Довгалюку, А. Дьоміну, В. Полеху, В. Солодуєву, С. Цесу, А. Янкелевичу та ін.

Традиція виконавства на валторні придбала ще одну відмінну рису-експресивність. Науковці відмічають, що ця манера гри характеризується активним використанням широкого спектру виражальних засобів - динамічних, тембрових, агогичних [4].

Отже, відмінністю російської валторнової иколи є особлива манера гри виконавці на валторні не грають, вони співають за допомогою валторни.

Невід'ємною складовою еволюції російскої валторнової школи в минулому столітті є їі бурхливий розвиток в Україні.

Українська школа валторнового виконавства - самобутнє творче явище, витоки якого знаходяться в традиціях сольної, оркестровоансамблевої практики музикантів минулого і сьогодення. Зараз в сфері виконавства на валторні триває процес накопичення практичного досвіду, збагачення репертуару i науково-методичного потенціалу, що дозволяє сказати про прогресивність впливу цього ходу розвитку на виховання нової генерації вітчизняних валторністів.

Становлення української школи валторнового виконавства можна віднестидо початку ХХ століття, яка спирається на оркестрову творчість 
композиторів-класиків. Музика композиторів багато в чому визначила виконавський стиль украінських валторністів, яка відрізняється співучістю звучання, широким динамічним діапазоном, красивим, виразним вібрато

Валторнова школа України відзначається оригінальністю та унікальністю звучання інструмента; має свою методику навчання, що забезпечена власним методичним матеріалом; має певну групу послідовників, які неодноразово підтверджували свою ефективність високими досягненнями на міжнародних конкурсах.

Істотна відмінність української валторнової школи від інших шкіл це художня іï домінанта. Якщо в американській та європейській школі головним завданням виховання валторніста $є$ техніка гри, яка забезпечує його необхідними знаннями, уміннями та навичками для втілення музично-художнього образу виконуваних творів, то українська школа навпаки - має завдання виховати не ремісника, а художника здатного до творчого самовираження. Прагнення до художньо-творчого самовираження через музичний образ твору саме створює у виконавця потребу у віртуозному володінні технічними виконавськими засобами.

Українські валторністи можуть по праву пишатися тим, що знають i пам'ятають всіх, хто розвиває валторнову школу, хто надав їй рівня високих професійних досягнень (Л. Андреєв, В. Бабенко, С. Госачинський, П. Грушовенко， В. Дмитров， П. Свстигнєєв， В. Марухно， В. Пилипчак, М. Станиславський, П. Чуріков, М. Юрченко, В. Яблонський та ін.).

Системоутворюючою ознакою виконавської школи, яка забезпечує цілісність системи, і що визначає всі інші ії параметри, є методика навчання: від неї залежить якість виконавства i рівень виконавчих досягнень. Сьогодні в українській школі валторнового виконавства спостерігається тенденція розширення інтонаційно-виразних засобів і ефектів гри, що сприяє, безсумнівно, підвищенню вимог до рівня розвитку виконавської майстерності, яка має на увазі технічнодосконале i художньо-виправдане відтворення музичного твору, ансамблевої та оркестрової партії. Для цього виконавський багаж валторніста повинен містити широкий комплекс технічних прийомів i способів, а також інтонаційно-виразних засобів і ефектів виконання.

На основі ретроспективного аналізу науково-методичних, архивних першоджерел 3'ясовано, що досліджуваний феномен $\epsilon$ складним утворенням, в якому система відповідних умінь і навичок забезпечує успішність художньої інтерпретації музичних творів, а також стає джерелом ефективної виконавської діяльності. 
1. Беленов Л. Д. Валторна: Монография. М.: Российская академия музыки имени Гнесиных, 2004. 320 c.

2. Левин С. Я. Духовые инструменты в истории музыкальной культуры. Л.: Музыка, 1973. $262 c$.

3. Полех Л.В. История создания и история интерпретации концертов для валторны В. А. Моцарта//Вопросы музыкальной педагогики. Вып. 10. М.: Музыка, 1991. C. 130-146.

4. Усов Ю. А. История отечественного исполнительства на духовых инструментах. М.: Музыка, 1975. $195 \mathrm{c.}$

5. Шоллар Ф. Школа игры на валторне. М., 1965. 140 с.

\section{References}

1. Belenov, L.D. (2004). French horn: Monograph [Valtorna: Monografiya]. Moscow, The Gnesins Russian Academy of Music. 320 p.

2. Levin, S. Ya. (1973). Wind Instruments in the History of Musical Culture [Duhovyie instrumentyi v istorii muzyikalnoy kulturyi]. Leningrad, Music. 262 p.

3. Polekh, L.V. (1991). History of the creation and history of the interpretation of concerts for the French horn of V.A. Mozart. Questions of musical pedagogy [Istoriya sozdaniya $i$ istoriya interpretatsii kontsertov dlya valtornyi V. A. Motsarta. Voprosyi muzyikalnoy pedagogiki]. Issue. 10. Moscow, Music. P. 130-146.

4. Usov, Yu. A. (1975). History of domestic performance on wind instruments [Istoriya otechestvennogo ispolnitelstva na duhovyih instrumentah]. Moscow, Music. 195 p.

5. Shollar, F. (1965). School of the French horn [Shkola igryi na valtorne]. Moscow, 140 p. 